\title{
Investigating the sustainability of water management in Alwahat, Libya
}

\author{
S. Alamin, A. Fewkes \& S. Goodhew \\ Nottingham Trent University, $U K$
}

\begin{abstract}
Libya is known to suffer from water shortages due to its location in desert and semi-desert terrains. The population is growing in Libya and because of the continuing reliance on groundwater supplies; a strain has been placed on this water resource. As a consequence, levels of underground water are decreasing, making it difficult and costly to extract. The problem has been made worse by the shortage of rainfall experienced in Libya in recent years. The threat to water resources has brought into focus the urgent need for planned action to manage water resources effectively as it is widely acknowledged that water is a major limiting factor in the socio-economic development of the country with a rapidly expanding population. The paper collates data from various sources to provide an overview of water use in the case study area of Alwahat which demonstrates the need to develop a sustainable water management strategy.

Keywords: sustainability, water management, irrigation, produced water, water policy, water users.
\end{abstract}

\section{Introduction}

Water covers two thirds of the earth's surface, but $97 \%$ of it is unfit for human use. Of the remaining 3\% two thirds are locked up in glaciers and snow. Approximately $1 \%$ is available for human consumption [1]. This residual amount should be enough to satisfy the needs of all water consumers in the world, but this is not the case [2]. The reasons for this are related the temporal and spacial variations in the availability of rainfall. Our misconduct and waste of the available water resources has complicated matters further. Human beings could hardly do anything to overcome the first barrier. However, with suitable and sensible water management we can rectify the second. Sustainable water 
strategies and their utilisation are of concern because of the potential socioeconomic impact on the whole society. Sustainable development reconciles society's developmental objectives with its environmental limits over the long term. It works to balance conflicts between economy and environment and between the present and the future [3]. The strategy proposed in this paper specifically identifies water as an example of a resource, which 'Should be used in ways that not endanger the resource or cause serious damage or pollution' [4].

The region of interest to this project is the Alwahat region in Libya, which lies within the Mediterranean Basin (Figure 1). By virtue of its geographical location and physical setting, the region does not receive adequate precipitation over most of its surface area. The demand on water is relatively high due to the warm climate prevailing most of the year. Demand is also increasing with time as a result of the high growth rate of the population. Since the surface water resources of many countries are limited, and the management of these sources is still incomplete, there is a growing need to cover, at least a certain part of the demand from groundwater resources. Experience has shown that groundwater abstraction requires certain precautions to be undertaken in order to safeguard the quality of the abstracted water. One should always remember that the deterioration of water quality is often slow, therefore it cannot be discovered except after some time [5]. The available water sources throughout the world are becoming depleted and this problem is aggravated by the rate at which populations are increasing especially in developing countries. In addition to increasing population, water resources are threatened by diminishing water quality caused by pollution, reduced quantity caused by overexploitation and the increase in water demand for agricultural use [6].

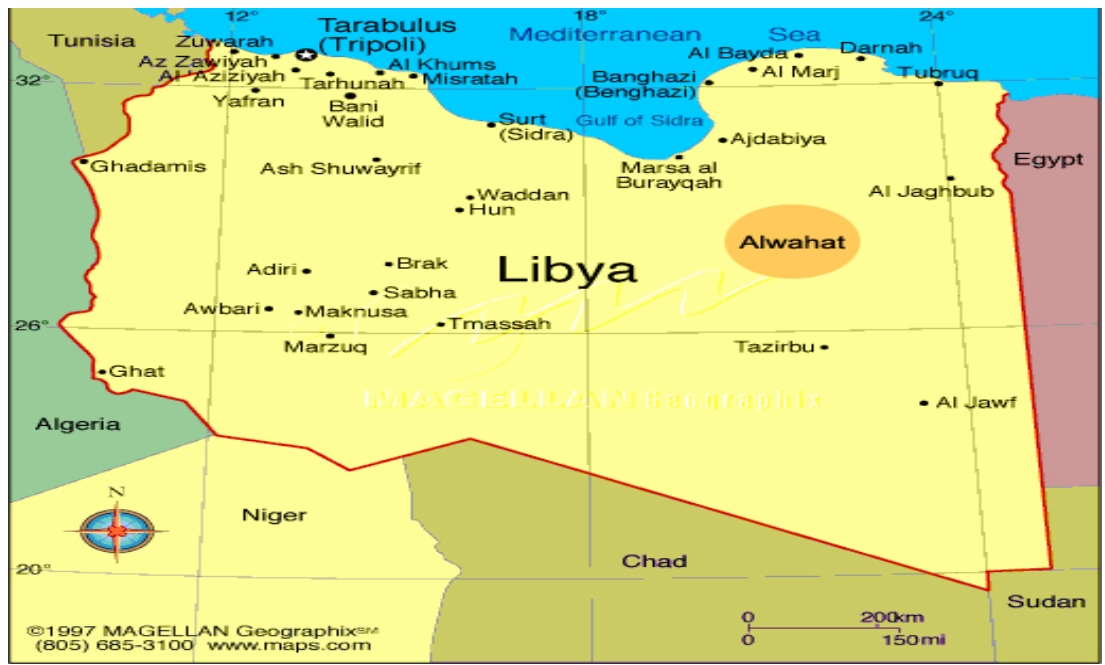

Figure 1: Map of Libya with the Alwahat area highlighted. (Source: www.maps.com.) 
Libya experiences scarcity of water due to its arid location [7]. Population growth and rising income, coupled with rapid urbanization, assure the continued steep increase in the demand for water for irrigation, industrial and municipal uses [8]. In many parts of the region demand is placing considerable pressure on existing supplies, stimulating mounting interest in finding new sources of water. Usually developing these sources requires large investment in dams, canals and other infrastructures, resulting in relatively high per unit costs [9]. The expected rises in costs of new sources of water suggest that policies and technologies to encourage more efficient use of existing supplies need to be put in place. The conditions for achieving increased efficiency are not well understood but are a necessary step towards developing water management policies which are an alternative to the development of new water resources.

Investigations and reviews of the water resources situation and management practices in Alwahat Libya by hydro-geologists [10], led to the conclusion that significant weaknesses and problems exist in water management polices and strategy. Alwahat is a major producer of dates in Libya and is totally dependent on irrigation for the development of its agriculture. Groundwater deterioration occurs in various forms, namely, pollution and excessive drawdown. Due to the low travel velocity of groundwater from the south region to the north towards Alwahat, depletion may not be detected immediately; and when detected, rehabilitation may either be impossible or very costly [11]. Accordingly, monitoring is one essential activity in the process of groundwater protection. Monitoring of groundwater should be carried out in strategy of integrated systems rather than simple networks [12]. Important tools in this process are databases, geographic information systems, and numerical models.

At present there is evidence that the groundwater table is declining at rates such that the economic life of the regions principal aquifer could be seriously threatened with "limited opportunity of extending the life time of the water transport system beyond 50 years" [13]. As the entire region's economy depends on irrigated agriculture, this situation poses a threat to exist living in the area [10]. In Alwahat the current pattern of water usage does not fully reflect the shift from water abundance to scarcity. The Government polices fail to take into consideration for excessive usage; indeed, the farmers are ignorant of the water scarcity [14]. This research explores the dimensions of the emerging water scarcity in Alwahat; examines the economic, social and environment impact on water sustainability, and the institutional factors influencing present patterns of water use. It also discusses a range of policy options to encourage farmers and oil companies to adopt patterns of usage more appropriate to present and prospective conditions of water scarcity. The aim is to demonstrate the potential value of water management policies to contribute towards the sustainability of groundwater supplies in Alwahat, Libya.

\section{Water resources in the Alwahat region}

Groundwater is the only source of fresh water in the Alwahat area. Its usage exceeds the rate of natural replacement, which results in a progressive lowering 
of the water table. This creates a situation, which puts in danger the prolonged existence and practical use of aquifers [15]. Moreover, lowering of the water table usually generates wider degradation of the environment and tertiary problems such as salt water intrusion [16]. Therefore, achieving stability between supply and demand is a necessary goal for the long term management of water resources in the Alwahat area. For Libya in general, and the study area in particular, most of groundwater monitoring network is focused on the control of large water development projects for agriculture or water transport. Groundwater abstraction from private farms, which corresponds to $47 \%$ of total present abstraction, is not currently monitored. Figure 2 shows the overall water balance projected for the year 2025. One reason for this increased shortfall is the increase in the standard of living and improvements in abstraction plants equipment [17].

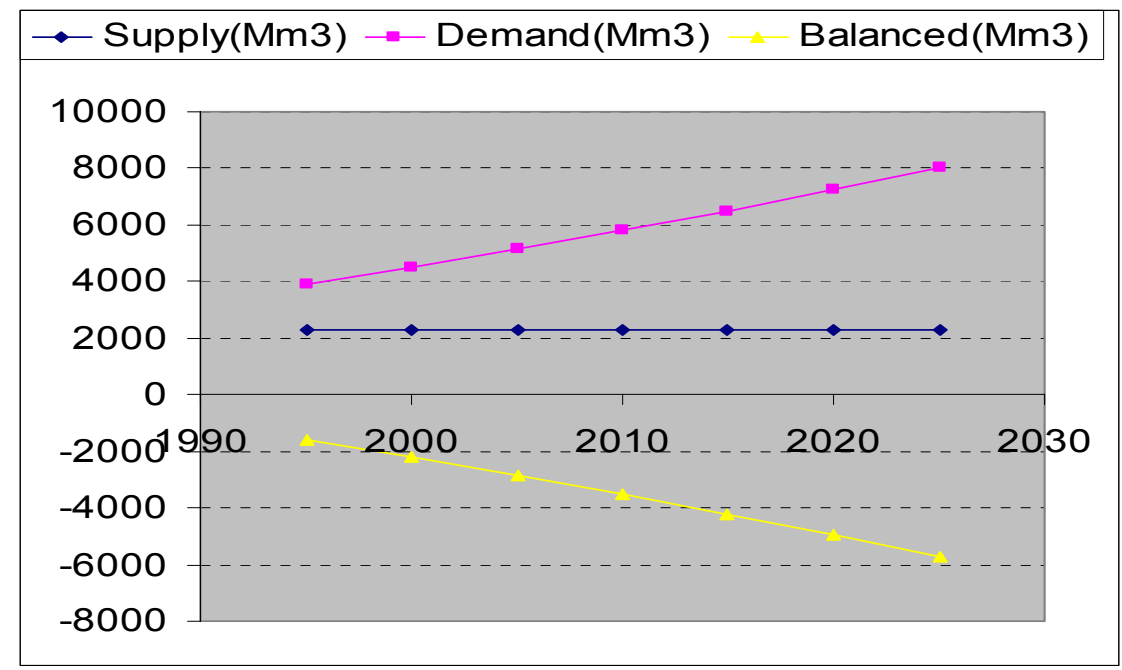

Figure 2: $\quad$ Projected water balance in Libya. (Source: GWA 1999.)

The quality of water varies across the area of study. Ground water is of a good quality in the north-south aquifer, this is because the aquifer lies close to the sources of natural recharge from the Sirir Basin Aquifer. In the area of north Alwahat near the oil settlement where groundwater over-abstraction has been most severe, saline intrusion has occurred. In the Jakera area, north of Alwahat, the water quality is too poor even to grow salt-tolerant crops such as dates. In general the quality of water drawn from wells is deteriorating with time [10]. The total number of inhabitants of the oasis, according to census figures of 2006 is 31,537 comprising both non-Libyans and Libyans. Using a population growth projection of $37 \%$ by 2031 , and a consumption rate of 350 litres per day per person, it is possible to estimate the consumption requirements of the population [18], which is shown in figure 3. 


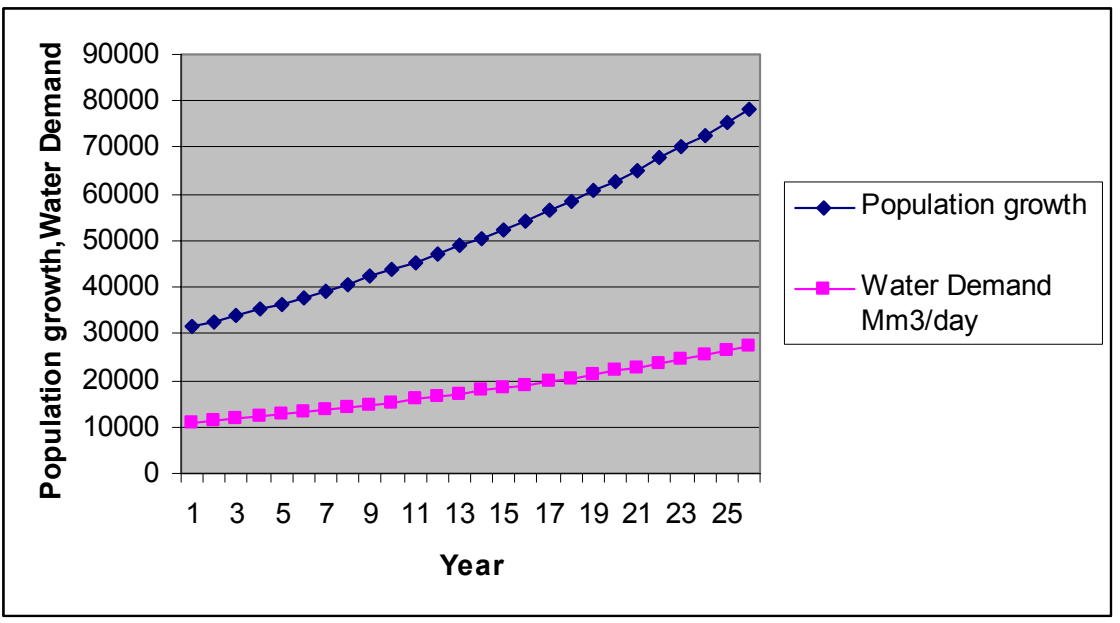

Figure 3: Projected increase in total water demand from 2006. (Source: Alskran, 2007.)

The realities of the water resources situation in Alwahat Libya represent a serious challenge to water resources management. In spite of the problems associated with water development, energy, domestic and industrial water supplies there is requirement that ground water resources be used much more effectively than at present. The challenge for water users, planners, policymakers is how best to achieve such development to contribute effectively towards meeting social and economic goals, while maintaining water resources on a sustainable, high quality basis and avoiding serious degradation of the physical environment and unacceptable social disruption.

\section{Domestic water in Alwahat}

Alwahat is facing increasingly difficult problems of water resources management (Figure 4). To overcome the problems, a new ethic of sustainable
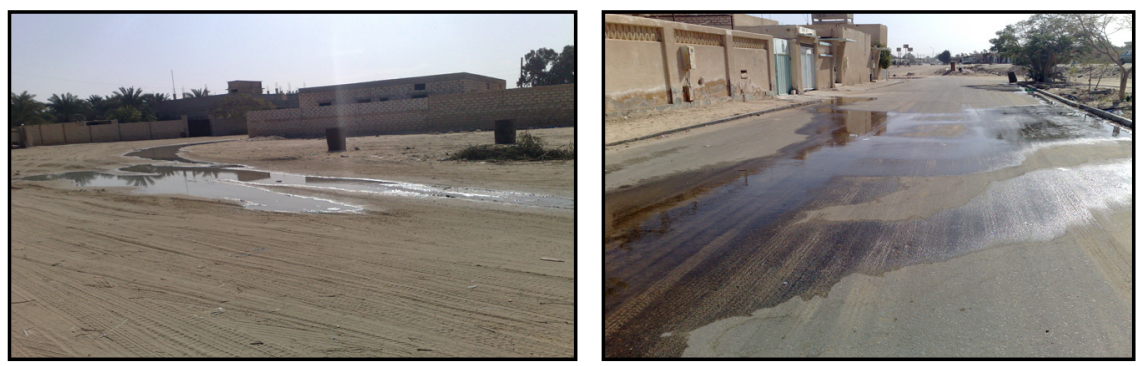

Figure 4: Evidence of urban water misuse in Alwahat (photos by the author, 2008). 
development is required. This should not only reinforce the established principles and technologies but also extend to integrated water resources management which includes water supply and waste water management. The present water extraction and aquifer sites in Alwahat are located $35 \mathrm{~km}$ east of Jalo. It consists of 16 production wells drilled between 1975-1990 [19]. Recent information indicates that fourteen wells have been abandoned by the General Water Authority (GWA) because of the unreliability of the water supply. Two wells are fully working from depths between $120-160 \mathrm{~m}$, with productivity of $25 \mathrm{l} / \mathrm{s}$, which equals $90 \mathrm{~m}^{3} / \mathrm{hr}$ for each well. Water is collected in to two storage tanks of $600 \mathrm{~m}^{3}$. The GWA in the study area faces challenges due to age of abstraction equipment and the size of the network pipeline which carries water between the three oases: Jalo, Awjalah and Jakera. To supplement supplies from these local wells water as also been supplied from the Great Man Made River Project (GMMRP) since 1993 subsequently this resource has become hugely important for the region [19]. The water supply from the GMMRP transfer project to Jalo, Jakera and the Alnafora oil company averages $10,500 \mathrm{~m}^{3} /$ day. Water supply from the transfer project to Awjalah is $2,500 \mathrm{~m}^{3} /$ day, but the GWA still applies for increased supplies from the GMMRP.

The GWA argue that the amount of water estimated for the region should be $14,365 \mathrm{~m}^{3} /$ day instead of current $10,500 \mathrm{~m}^{3} /$ day sourced from (GMMRP) for Jalo and Jakera and Alnafora oil company. For Awjalah to be $5420 \mathrm{~m}^{3} /$ day instead of $2500 \mathrm{~m}^{3} /$ day. In responding to this argument the GWA in Libya explain that the capacity of the water supply network has insufficient capacity. The total renewable water resources in Libya are estimated at $600 \times 10^{6} \mathrm{~m}^{3} / \mathrm{yr}$. This means that $87 \%$ of the present groundwater use is coming from nonrenewable resources

\section{Water and agriculture}

As the world population increases, demand for food production increases. This implies that farmers require more water to meet rising production needs. In agriculture, as in industry, there are numerous locations where real problems exist [20]. The cultivatable area of Libya is estimated at about 2.2 million ha ( $1.2 \%$ of the total area), with 1.8 million ha for annual crops and 0.3 million ha for permanent crops in addition to 13.3 million ha of permanent pastures. Agriculture contributes approximately 9\% of GDP and provides employment for about $5 \%$ of the total economically active population [20].

In the Alwahat area of Jalo and Awjalah, a state project was implemented in early $80 \mathrm{~s}$, consisting of 101 farms of 6 ha each. Water was to be supplied by a well field located a few kilometres south where water was found of better quality in the post Middle Miocene aquifer. 33 wells in three parallel rows of 11 wells were drilled from 1977 to 1981 but only one row was connected to the irrigation network of the farms. Now only 4 out of the 11 wells are in operating conditions and each well has a capacity of approximately $50 \mathrm{l} / \mathrm{s}$. In view of the insufficient amount of water available for irrigation, the farmers drilled their own wells at depths ranging from 60 to $100 \mathrm{~m}$ but supplying water of poor quality $(2.5$ to $5 \mathrm{~g} / 1$ 
TDS) to be mixed with the better quality water from the deep wells. Information gathered from the agricultural engineers working in Jalo suggests that most of the 600 ha originally planned are now under irrigation, mostly with shallow well water [21].

Private irrigation has rapidly developed in Jalo and Awjlah based on shallow drilled wells each with a capacity ranging from 4 to $7 \mathrm{l} / \mathrm{s}$ but with poor quality water. Nevertheless, the private irrigation area is now estimated at 3500 ha approximately 2000 ha in Jalo, 1000 ha in Awjlah and 500 ha in Jekara. The main crops grown with the brackish water are date palms and tomatoes. The average yearly water abstraction is estimated to be $60-80$ million $\mathrm{m}^{3} / \mathrm{yr}$ [14].

\section{Water and the oil industry}

Libya's onshore oil production is located mainly in three geological trends of the Sirte Basin: Firstly, the western fairway, which includes several large oil fields (Samah, Beida, Raguba, Dahra-Hofra, and Bahi); secondly, the north of the country, which contains the Defa-Waha and Nasser fields, as well as the Hateiba gas field; thirdly, an eastern trend, which has several fields, containing approximately 80 percent of Libya's proven oil reserves and accounts for 90 percent of production [22].

Oil was discovered in the Jalo basin in 1961. This gave rise to a distribution of production fields and pipelines across Alwahat [23] (Figure 5). Alwahat is of considerable importance in the transport of transport because is lactation in the centre of Libya's major oilfields cluster. Despite this, the oil industry has minimal impact on the local domestic economy and maximum environmental

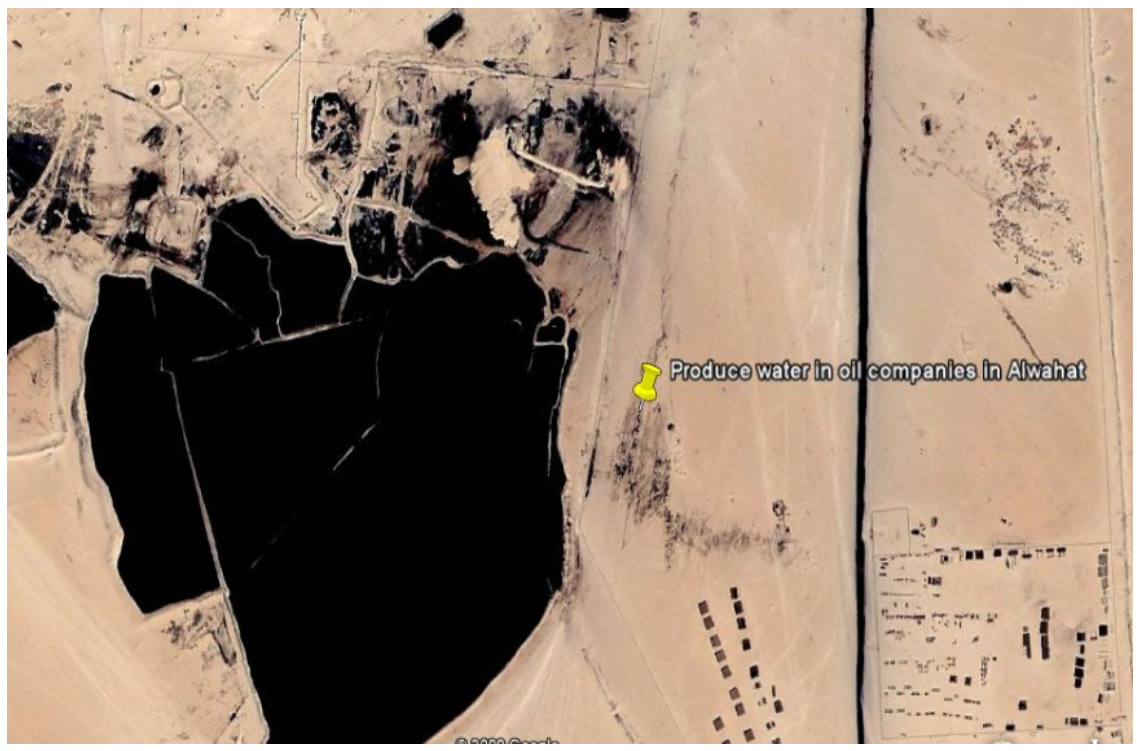

Figure 5: $\quad$ Produced water in the Alwahat region. (Source: Google Earth.) 
impact. This is due to the fact that the oil companies are self-sufficient in technological services and local manpower are only required in the fields of transport and construction. The upstream petroleum industry provides essential petroleum products. The use of petroleum products is a major contributor to the present standard of living.

The activities of finding and producing petroleum, however, can have an impact on the environment, from the release of waste into the environment in unsafe concentrations. This waste includes hydrocarbons, solids contaminated with hydrocarbon, water contaminated with a variety of dissolved and suspended solids, and a wide variety of chemicals [24]. Some of this waste has significant adverse effects on the environment. One of these problems is called 'produced water', and can be defined as follows: "Mainly salty water trapped in the reservoir rock and brought up along with oil or gas during production" [25]. This massive volume of produced water from an oil well can be more than 10 times the volume of oil produced [26]. In desert arid regions, where fresh water is scarce and costly, it may be economically viable to reuse the massive amount of produced water for agricultural and domestic purposes. Ayesha [27] clearly shows through the concentration of oil in samples of water from the two study areas, where the results were higher than international safety standards (Figures 6 and 7).

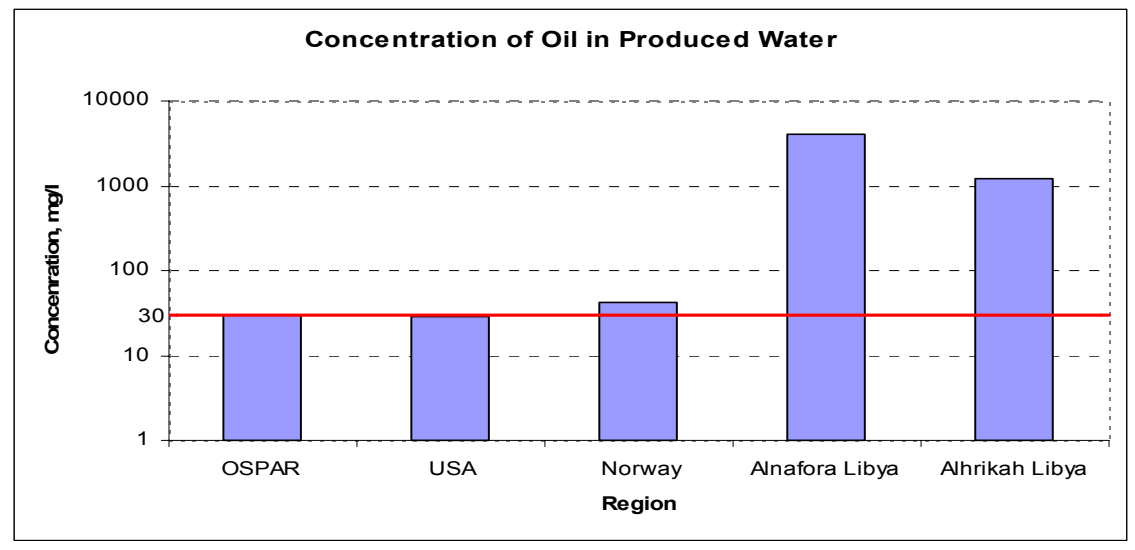

Figure 6: Allowable concentration of oil in produced water. (Source: Ayesha 1990.)

In addition to these problems, Alwahat's population also suffers from environmental pollution from the extraction of oil and gas from fields around the area, the consequence is that the health of humans and animals is put at risk. More alarmingly, the increase of hydrogen sulphide in the air presents a significant hazard for human health, especially in children and pregnant women in the area. Anecdotal evidence, and personal experience in the region, shows that this pollution is likely responsible for the increased proportion of miscarriages and reduced fertility in the local population [28]. 


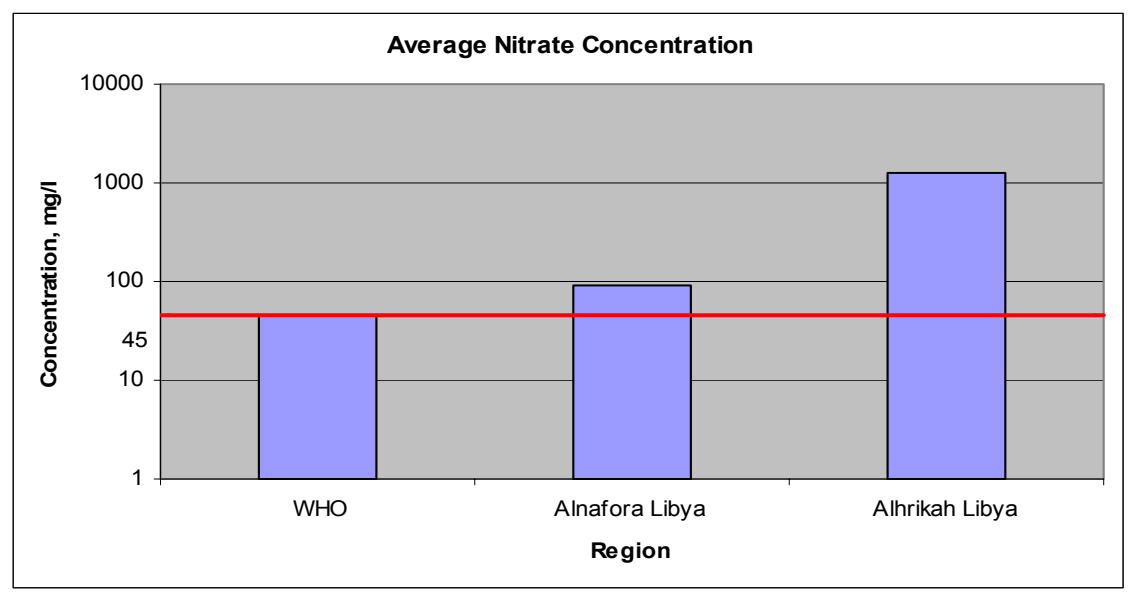

Figure 7: Average Nitrate concentration in produced water. (Source: Ayesha 1990.)

\section{Discussion and conclusions}

Whilst Libya is among the few African countries with modern water legislation, its policy on water management is largely ineffective because it is hardly enforced. The reasons for this are to be found in the social fabric of the country. Agricultural policy allows the planting of date palms too close to polluted water sources. This research project identifies the following barriers to sustainability:

- Improper irrigation and drainage practice has resulted in substantial degradation of soil in Alwahat. The planned use of water from the GMMRP for irrigation in Alwahat where brackish aquifers exist at shallow depths may also result in water logging and salinity problem if appropriate irrigation and drainage techniques are not applied.

- Ignorance of the problem. People are not aware of the issues; this is partly the government's responsibility to educate its people.

- Polluting oil companies, which need greater regulation.

- Conflict of interest between stockholders in oil companies, government, water authorities, and the private sector.

- Lack of communication and cooperation between water suppliers and users.

- Lack of data and also no access to some data e.g. oil companies' waste.

- Attitude to water as a resource: people regard water as a shared resource which is free, and they don't value water because they do not pay for it. As a result, when water supply is increased, people waste more water in the area; when electricity began be charged, usage decreased. 
Water abstraction either for local agricultural projects or form the GMMRP to the region will cause a significant water level decline in the aquifer, due to the non-renewability of the water resources. This will gradually induce the disappearance of natural vegetation which is vital in the area. Alwahat exemplifies the case of shared water resources and any strategy in the area may directly or indirectly affect the other sectors, however a national plan should be formulated and an investigation on the long-term impact of strategies undertaken.

Shortage and misuse of fresh water pose a serious and growing threat to sustainable development and protection of the environment. Problems related to sustainable water use are generally more serious in arid areas due to the hydrogeological complexity of water systems in such areas. Therefore, water use policies should be based on these prevailing issues and driving forces. The policy should also consider all components of the environment. Transparency of the policy formulation process and general public approval are the key elements to achieve the necessary objectives.

\section{References}

[1] Serageldin, I. Toward Sustainable Management of Water Resources. The World Bank, Washington DC. 1995.

[2] Omer, S. International Workshop on Management of Aquifer Resources in Africa. Tripoli, Libya. 2002.

[3] National Academy Press. A Transition toward Sustainability. Washington DC. 1999.

[4] Benoit, G. and Comeau, A. A Sustainable Future for the Mediterranean, The Blue Plan's Environment \& Development Outlook. [online] Earth scan, London. www.planbleu.org. 2005.

[5] Shiklo Manov, I.A. World freshwater resources. In: Water in Crisis: A Guide to the World's Fresh Water Resources. P. Gleick (Ed.). Oxford University Press. 13-24. 1993.

[6] Engleman, R. and Leory, P. Sustainable water population and future of renewable water supplies, population and environment program. 1993.

[7] Pastel, S.L., Daily, G.C. and Ehrlich, P.R. (1996) Human appropriation of renewable fresh water. Science 271: 785-787.

[8] London Model. Agreements for Sustainable Water Management Systems Development. Oxford University Press, Oxford. 2004.

[9] Edmunds, W.M. Groundwater salinity and environment change In Isotope techniques in stud of environment change. Vienna: IAEA. 508-518.1997

[10] Omer, D. Personal interview. Alwahat; Jalo. 15 March 2009.

[11] Abd el Gelil Abd Allah K., Hydro-geology of El Kufra area. Thesis. Cairo University. 1996.

[12] Salem. Groundwater resources of Libya, Present and Future requirement (Arabic). Tripoli. 1991.

[13] Ghamim M. Ibrahim, \& Mohamed B. Rashed. Groundwater Situation in a region of northwest Libya .Tripoli 1999. 
[14] Pallas, P. and Omer, S. Water resources Utilisation and management of the socialist people of Arab Jamahiriya. Tripoli. 1999.

[15] Omer, G. Personal interview. Alwahat, Jalo. 10 March 2009.

[16] Edmunds, W.M. Integrated geochemical and isotopic evaluation of regional aquifer systems in arid regions. Proceedings of the international Conference. Tripoli. 1999.

[17] El Remely, I. Water resources study of zone $V$ Alkufra and Sirt basins. Tripoli, (Ed. Jones, M.T.). 1983.

[18] Salem, Alaskans. Projected increase in total water in Alwhat area. 2007.

[19] G.W.A. Letter from Water Authority Sector in Alwhat Jalo to General Water Authority Libya. Ref no: 2008-4-1-132. 2008.

[20] Overman M. Water solution to a problem of supply and Demand. Open University. 1976.

[21] Palls, P. Report of the Senior hydro-Geologist Consultant. 1999.

[22] EIA, Libya Country Analysis Brief, www.eia.done.gov/emeu/cabs/ libya.html 2005

[23] Waeil, A. Planning for Safety Inside Arabian Gulf Oil Company. M.Sc. dissertation, Teesside University. 52-53. 2003.

[24] Joint E \& P Forum / UNEP. Environmental management in oil and gas exploration and production: an overview of issues and management approach. Technical publication (report 37). 1-25. 1997.

[25] Offshore Discharge from Oil and Gas Operation. http/www.gomr.mms.gov/homepg/offshore/egom/factsheet.html 2008.

[26] Stephenson, M.T. A Survey of Produced Water Studies. Produced Water. J.P. Ray and F.R. Englehart (eds.), Plenum Press., pp .New York. 548-603.

[27] Ayesha, J. Estimate the volumes and quality of produced water in two case studies. M.Sc. thesis. Academy of Graduate study department. (Arabic). 1999.

[28] Ballal, A. Oil Companies and their impacts on Alwaha Libya. Report. Jalo. (Arabic) 2006. 